R. Ogórek, M. Dyląg, Z. Višňovská, D. Tančinová, and D. Zalewski - Speleomycology of air and rock surfaces in Driny Cave (Lesser Carpathians, Slovakia). Journal of Cave and Karst Studies, v. 78, no. 2, p. 119-127. DOI: 10.4311/2015MB0128

\title{
SPELEOMYCOLOGY OF AIR AND ROCK SURFACES IN DRINY CAVE (LESSER CARPATHIANS, SLOVAKIA)
}

\author{
RafaŁ OGÓrek ${ }^{1 *}$, Mariusz DyląG ${ }^{1}$, ZuZana VišŇOvská², \\ DANA TANČINOVÁ ${ }^{3}$, AND DARIUSZ ZALEWSKI ${ }^{4}$
}

\begin{abstract}
This paper is a speleomycological report from Driny Cave in the Lesser Carpathian Mountains, Slovakia. The samples were collected in July 2014 from one location outside and five locations inside the cave. To examine the air, the Air Ideal 3P sampler was used. Samples from the rock surfaces were collected using sterile swabs wetted in physiological saline $(0.85 \% \mathrm{NaCl})$. The density of filamentous fungi isolated from the air inside and outside the cave ranged from 89.6 to 1284.7 colony-forming units per $1 \mathrm{~m}^{3}$ of air and from 38.3 to $588.5 \mathrm{CFU}$ per $\mathrm{m}^{2}$ of the rock surface. Six species of filamentous fungi were isolated from the external air samples, and eleven species of filamentous fungi and three species of yeast-like fungi from the internal air samples. Fungi belonging to the Cladosporium genus were the most frequently isolated species from the internal and the external air. Six species of filamentous fungi and two species of yeast-like fungi were isolated from the surface of the rocks inside the cave and only two species from the samples collected outside the cave. Among the fungi isolated from the rock surfaces most frequently were Penicillium chrysogenum, P. granulatum, and Trichoderma harzianum. The concentration of airborne fungi inside the cave did not exceed official limits and norms stated as safe for health of tourists. However, the species found here can cause degradation of rock surfaces.
\end{abstract}

\section{INTRODUCTION}

Mycological research on caves and underground facilities has been conducted since the 1960s (Balabanoff, 1967; Brashear et al., 1966; Al-Doory and Rhoades, 1968). However, the term speleomycology was first introduced by Polish scientists in 2014 as a name for all kinds of investigations that focus on exploration of caves and their underground mycobiota (Pusz et al., 2014).

Ecosystems such as caves or underground facilities created by man have stable, low temperatures and very restricted nutrients during the year (Poulson and White, 1969). Therefore, the majority of fungi underground are present as spores or conidia carried by water, air currents, animals such as bats and arthropods, or humans (Kubátová and Dvořák, 2005; Jurado et al., 2010; Chelius et al., 2009; Vanderwolf et al., 2013; Griffin et al., 2014).

As shown previously (Ogórek et al., 2014a, 2014b, 2014c), bioaerosols from the external environment most strongly influence the percentage composition of fungi in caves and other underground sites. Tourist activities are also very important, because they may have a serious impact on the hypogean system (Taylor et al., 2013). Visitors can enrich the environment with organic and inorganic matter, compact soil, and change the pristine climate through, inter alia, an increase in temperature and the concentration of carbon dioxide (Pulido-Bosch et al., 1997; Barton, 2006; Barton and Northup, 2007). Tourist activities may also favor the dispersion and import of new microbes, even those that are potentially pathogenic for humans and animals (Barton, 2006; Cury et al., 2001).

Each underground site may be divided into three zones: the twilight zone, the middle zone and the dark zone (Karkun et al., 2012). The area most susceptible to external conditions is the twilight zone, which is located at the entrance or exit and the vicinity of ventilation shafts (Poulson and White, 1969; Koilraj and Marimuthu, 1998). The most fungi typically are isolated from this zone (Ogórek et al., 2014a, $2014 b, 2014 c)$. In the middle zone relative darkness prevails, with fluctuating temperature. In the dark zone, in which total darkness and constant temperature prevail, the least fungi are usually isolated (Poulson and White, 1969; Koilraj and Marimuthu, 1998; Pusz et al., 2015).

Fungi and their secondary metabolites present in the atmosphere play a significant role in air pollution (Papuas et al., 2000). Thus this type of bioaerosol can affect the health of humans or animals. Moreover, the cave mycobiota are very important for underground ecology, because fungi and bacteria probably constitute the major source of

\footnotetext{
*Corresponding author: rafal-ogorek@wp.pl

${ }^{1}$ University of Wroclaw, Institute of Genetics and Microbiology, Department of Genetics, Przybyszewskiego Street 63/77, 51-148 Wroclaw, Poland

${ }^{2}$ State Nature Conservancy of the Slovak Republic, Slovak Caves Administration, Hodžova 11, 031-01 Liptovský Mikuláš, Slovakia

${ }^{3}$ Slovak University of Agriculture in Nitra, Department of Microbiology, Tr. Hlinku 2, 949-76 Nitra, Slovakia

${ }^{4}$ Wrocław University of Environmental and Life Sciences, Department of Genetics, Plant Breeding and Seed Production, pl. Grunwaldzki 24a, 50-363 Wrocław, Poland
} 
food for other organisms (Sustr et al., 2005; Walochnik and Mulec, 2009; Bastian et al., 2010). Fungi can also cause biodeterioration of rocks through biochemical and mechanical activities (Kalogerakis et al., 2005; Ogórek et al., 2014c; Sterflinger, 2000). Biochemical activities based on secondary metabolites of fungi that act on rocks, such as acids and other metabolites with metal-chelating properties or pigments, can cause foxing on the surface of rocks (Sterflinger, 2000; Gu 2003; Barton and Northup, 2007; Cwalina, 2008; Li et al., 2008). The biomechanical impact of fungi on rocks is less important than biochemical, and it can occur, for example, through penetration by fungal hyphae into decayed limestone and by burrowing into otherwise intact minerals (Scheerer et al., 2009; Sterflinger, 2000).

This study aimed to carry out speleomycological research in Driny Cave, and our research focused on two goals, the mycological analysis of species composition of the fungi found in the air and the rock surface inside and outside of Driny Cave and quantifying their concentrations.

\section{Materials AND Methods}

Driny Cave is located in the Smolenice Karst in the Lesser Carpathian Mountains, southwest from Smolenice, in the Trnava district and near the recreation resort Jahodník. Geographic coordinates of the cave are $48^{\circ} 50^{\prime} 04^{\prime \prime} \mathrm{N}, 17^{\circ} 40^{\prime} 20^{\prime \prime}$ E. It was formed in brown-grey Lower Cretaceous chert limestones of the Vysocký Nappe by corrosion by atmospheric waters penetrating along tectonic faults. Its entrance is situated on the western slope of Driny Hill and lies at an elevation of $399 \mathrm{~m}$ a.s.1. Its length is $680 \mathrm{~m}$ and its vertical span $40 \mathrm{~m}$. It consists of narrow fissure passages, from one to three meters wide, and a medium-size room, Slovak Speleological Society Hall, formed mostly at the intersection of tectonic faults. The discovery chimney descends to $36 \mathrm{~m}$ depth from the upper opening to the intersection of the Entrance Passage. A rich sinter fill decorates underground fissures. Flowstone draperies with indented facing are typical for this cave. Flowstone waterfalls and structures, pagoda-like stalagmites, and various forms of stalactites commonly occur here. Also small flowstone pools, supplied with water by percolating rainfall, can be found. The cave was opened to the public in 1935 with provisional electric lighting for $175 \mathrm{~m}$. Currently the length of the tourist path is $410 \mathrm{~m}$ (Bella et al., 2001; Bella, 2003). This cave is one of the most important underground localities for bats in Slovakia, and the dominant species is the lesser horseshoe bat Rhinolophus hipposideros, with 100 to 150 individuals (Lehotská and Lehotský, 2009). In 2014 Driny Cave was visited by 31,859 people (Nudziková, 2014).

The samples were taken before the tourists arrived on July 25, 2014 from an outdoor location about $3 \mathrm{~m}$ in front of the entrance to the cave and from five locations inside (Fig. 1). The air temperature and relative humidity were measured using a thermohygrometer (LB-522, LAB-EL) six times in each location.

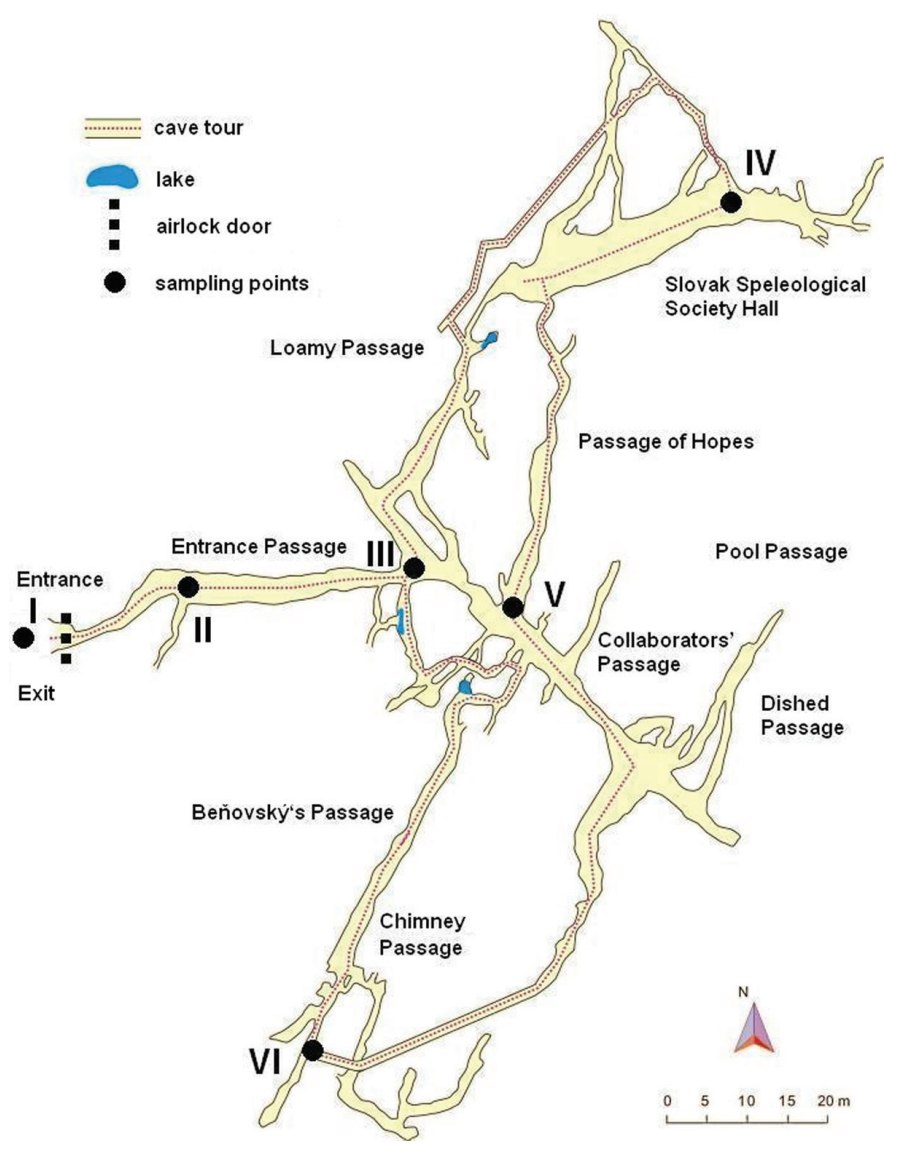

Figure 1. Map of the tourist route and the sampling locations in Driny Cave.

Potato Dextrose Agar medium (PDA, Biocorp) was used for the isolation of fungi from the air, the rock surface, and for the identification of some species. Czapek-Dox Agar medium (1.2\% agar, Biocorp) and Malt Extract Agar medium (MEA, Biocorp) were used for the identification of species belonging to Penicillium and Aspergillus genera. Sabouraud Agar medium (4\% dextrose, $2 \%$ agar, $1 \%$ peptone, A\&A Biotechnology) was used for identification of yeast-like fungi.

The air sampler (Air Ideal 3P) was programmed for the air sample volumes of $100 \mathrm{~L}$ and $150 \mathrm{~L}$. Six replicates of air were collected at each location. The sampler was positioned $1.5 \mathrm{~m}$ above the level of the cave floor.

Swabs of the rock surface were made using sterile swabs wetted in physiological saline $(0.85 \% \mathrm{NaCl})$ stored in transport tubes (plastic applicator, viscose swab, of $15 \mathrm{~cm}$ length). Every location was sampled with three swabs from a surface area of $1.0 \mathrm{~cm}^{2}$ at a height of $1 \mathrm{~m}$ and $2 \mathrm{~m}$ above the floor. The samples from each collection point were put together into one $50 \mathrm{~mL}$ Erlenmeyer flask containing $10 \mathrm{~mL}$ of sterile distilled water, and they were shaken for 20 minutes. After shaking, the samples were placed in a Petri dish, on the solidified PDA medium, using serial dilution technique in three replicates for the three incubation temperatures. 
R. OGóReK, M. DyląG, Z. VišŇOvSKÁ, D. TANČINOVÁ, AND D. ZALEWSKI

Table 1. Filamentous fungi and yeast-like fungi isolated from the air and the rock surfaces inside and outside Driny Cave on July 25, 2014. A "+" indicates that the species was found.

\begin{tabular}{|c|c|c|c|c|}
\hline \multirow[b]{2}{*}{ Species } & \multicolumn{2}{|c|}{ Air } & \multicolumn{2}{|c|}{ Rock Surface } \\
\hline & Outside & Inside & Outside & Inside \\
\hline Alternaria alternata (Fr.) Keissl. & + & + & & \\
\hline Aspergillus fumigatus Fresen. & & + & + & + \\
\hline Aspergillus niger Tiegh & + & & & \\
\hline Candida albicans (C.P. Robin) Berkhout & & + & & + \\
\hline Cladosporium cladosporioides (Fresen.) G.A. de Vries & + & + & & \\
\hline Cladosporium herbarum (Pers.) Link & + & + & & \\
\hline Epicoccum nigrum Link & + & + & & \\
\hline Fusarium equiseti (Corda) Sacc. & & + & & \\
\hline Mucor hiemalis Wehmer & & + & & + \\
\hline Penicillium chrysogenum Thom & & + & + & + \\
\hline Penicillium granulatum Rainier & & + & & + \\
\hline Penicillium urticae Rainier & + & + & & \\
\hline Phoma fimeti Brunaud & & + & & \\
\hline Rhizopus stolonifer (Ehrenb.) Vuill. & & & & + \\
\hline Rhodotorula glutinis (Fresen.) F.C. Harrison & & + & & \\
\hline Rhodotorula rubra (Schimon) F.C. Harrison & & + & & + \\
\hline Trichoderma harzianum Rifai & & & & + \\
\hline Total Species & 6 & 14 & 2 & 8 \\
\hline
\end{tabular}

After incubation at 15,20 , or $25^{\circ} \mathrm{C}$ for 4 to 14 days in darkness, fungal colonies were counted as averages from the replicates at all incubation temperatures and identified. The species identification was based on macro- and microscopic observations of the morphology of hyphae, conidia, and sporangia of the colonies that had grown on culture media. The filamentous fungi were identified using diagnostic keys and descriptions by Pitt and Hocking (2009) and Watanabe (2010). The yeast-like fungi were identified by diagnostic key and descriptions by Kurtzman and Fell (1998) and Barnett et al. (2000).

The results were analyzed by ANOVA, using Statistica 12.0 package. Means were compared using Tukey Honest Significant Differences test at $\alpha \leq 0.05$.

\section{RESULTS}

More species of fungi (12 filamentous fungi and 3 yeastlike fungi) were isolated from the air samples than from the rock surfaces (respectively 6 and 2). Species Rhizopus stolonifer and Trichoderma harzianum were cultured only from the rock, whereas Alternaria alternata, Aspergillus niger, Cladosporium spp., Epicoccum nigrum, Fusarium equiseti, Penicillium urticae, Phoma fimeti, and Rhodotorula glutinis were cultured only from the sampled air (Table 1).

Six species of filamentous fungi were isolated from the air sampled outside the cave, whereas from the inside air eleven species of filamentous fungi and three species of yeast-like fungi were cultured. Aspergillus fumigatus, Fusarium equiseti, Mucor hiemalis, Penicillium chrysogenum, P. granulatum,
Phoma fimeti, and yeast-like fungi were present only in the indoor air compared to the outside air, and $A$. niger was isolated only from the outside air. From the rock surfaces inside the cave, six species of filamentous fungi and two yeast-like fungi were isolated, but only two species were isolated from the samples collected outside the cave. Species such as Candida albicans, M. hiemalis, P. granulatum, Rhizopus stolonifer, Rhodotorula rubra, and Trichoderma harzianum were isolated only from the surfaces inside the cave (Table 1).

We detected an association between the air temperature and the content of fungi in the air and, to some extent, on the rocks. The temperature of the air outside Driny Cave $\left(25.5^{\circ} \mathrm{C}\right)$ was higher than inside $\left(7.6-8.6{ }^{\circ} \mathrm{C}\right)$, whereas the air humidity was higher inside the cave (92.0-93.3\%) than outside $(52.6 \%)$. The concentration of fungi increased with the increase in the air temperature (Fig. 2).

The density of airborne fungi isolated from the air samples was $1284.7 \pm 405.8$ colony-forming units (CFU) per $\mathrm{m}^{3}$ of outside air and from $89.6 \pm 25.4$ to $217.5 \pm 34.7$ $\mathrm{CFU}$ per $\mathrm{m}^{3}$ for the indoor air samples, and it varied significantly between studied locations. The majority of fungi were isolated from the air outside the cave; $\mathrm{P}_{\mathrm{I}, \mathrm{V}}=$ 0.0000001 . The highest number of species isolated from the indoor air was noted for Location $\mathrm{V}$, the Passage of Hopes, and the smallest number was noted for Location III, the Entrance Passage; $\mathrm{P}_{\mathrm{III}, \mathrm{v}}=0.0000001$ (Table 2, Figs. 1 and 2). The number of CFU obtained from the rock surfaces inside and outside the cave ranged from $38.3 \pm$ 13.3 to $588.5 \pm 134.5 \mathrm{CFU}$ per $\mathrm{cm}^{2}$. The highest number 


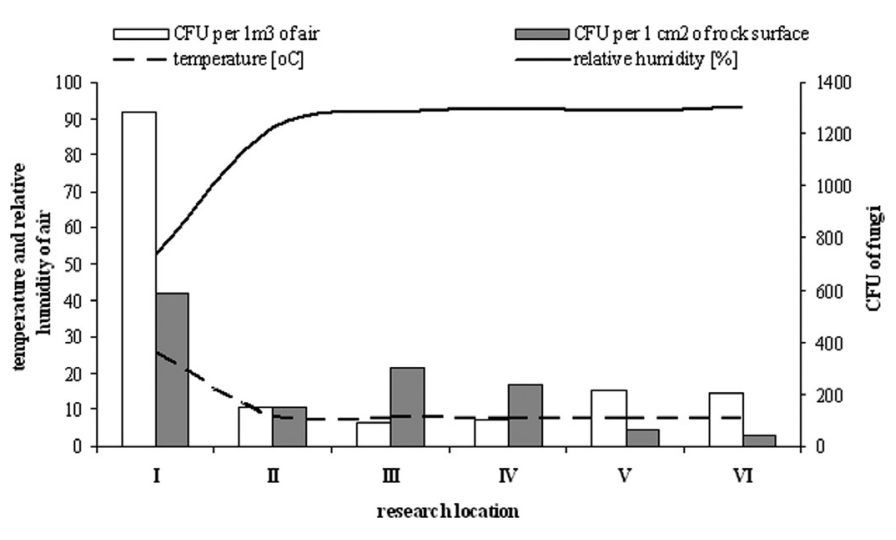

Figure 2. The climate parameters and measured concentrations of fungal spores at the sampled locations in Driny Cave on July 25, 2014. Location $I$ is outside the cave entrance.

of fungal propagules isolated from the rock surface was found outside the cave at Location I, whereas the smallest number was observed from Location VI, the Chimney Passage; $\mathrm{P}_{\mathrm{I}, \mathrm{VI}}=0.0000001$ (Table 3, Figs. 1 and 2).

The fungus most frequently isolated from the air outside and inside of Driny Cave was Cladosporium cladosporioides. The exception was Location VI, the Chimney Passage, where the most frequently isolated species was Penicillium urticae. All other fungi were much less common in the outside air $\left(\mathrm{P}_{\text {C. cladosporioides, E. nigrum }}=0.0000001\right)$. The same was true for fungi isolated from Location III, Entrance Passage $\left(\mathrm{P}_{\text {C.cladosporioides, P. urticae }}=0.0000001\right)$ and from Location IV, the Slovak Speleological Society Hall $\left(\mathrm{P}_{\text {C. } \text { cladosporioides, P. urticae }}=0.0000001\right)$. On the other hand, Rhodotorula spp. were the least frequently isolated species from Location II, also in the Entrance Passage $\left(\mathrm{P}_{C}\right.$. albicans, $R_{\text {. }}$ glutinis $\left.=0.0081021\right)$. Aspergillus fumigatus, Candida albicans, Penicillium granulatum and Rhodotorula rubra $\left(\mathrm{P}_{P \text {. urticae, A. fumigatus }}=0.0149291\right)$ were rarest the Passage of Hopesand Alternaria alternata, C. albicans, $P$. chrysogenum and $R$. rubra $\left(\mathrm{P}_{C}\right.$. cladosporioides, $A$. alternata $=$ $0.0000002)$ were rarest at Location VI, the Chimney Passage (Table 2, Fig. 1, 3).

The species that most frequently occurred on the rock surface in three of seven tested locations was Penicillium chrysogenum, whereas the least frequent were Rhizopus stolonifer, Rhodotorula rubra, and Trichoderma harzianum, all of which were found only at Location II. Penicillium chrysogenum was the most numerous species isolated from Location I outside the cave $\left(\mathrm{P}_{P}\right.$. chrysogenum, A. fumigatus $=$ 0.0000001), Location III in the Entrance Passage $\left(\mathrm{P}_{P}\right.$. chrysogenum, A. fumigatus $\left.=0.0000001\right)$, and Location VI in the Chimney Passage $\left(\mathrm{P}_{P}\right.$. chrysogenum, c. albicans $\left.=0.0000002\right)$. The same was true for $T$. harzianum from Location II in the Entrance Passage $\left(\mathrm{P}_{R}\right.$ rubra, T. harzianum $\left.=0.0000001\right)$ and for $P$. granulatum from Location IV, the Slovak Speleological Society Hall $\left(\mathrm{P}_{P}\right.$. granulatum, $P$. chrysogenum $\left.=0.0000001\right)$ and Location $\mathrm{V}$, the Passage of Hopes $\left(\mathrm{P}_{M}\right.$. hiemalis, $P$. granulatum $=$ 0.0000001 ) (Table 3, Fig. 1 and 3).

\section{DisCUSSION}

Mycological evaluation of the air was performed according to the collision method using the Air Ideal 3P sampler and Petri dishes with appropriate solidified culture medium. In this method, the suction force ensures adherence of all the fungal propagules to the surface of a suitable culture medium. Furthermore, we can accurately determine their number per volume of the sucked air. This method is also suitable for evaluation of air for the concentration of bacteria and viruses (Kaiser and Wolski, 2007; Wiejak, 2011). It is very fast and easy to take a large number of samples during one day. Moreover, air samplers, such as the Air Ideal 3P sampler, are small in size, so they are useful for application in difficult conditions such as underground sites (Ogórek and Lejman, 2015).

Ogórek et al. (2014a, 2014b, 2014c) and Pusz et al. (2014, 2015), who studied fungi from air in underground sites, reported that higher levels of fungi were isolated from outside sites than from inside, as found in our study. Ecosystems such as underground sites, when compared to the external environment, are very unfavorable for survival and development of fungi due to the relatively stable low temperatures and very restricted availability of organic matter (Poulson and White, 1969; Barton and Northup, 2007). The concentration of fungal propagules in the air of Driny Cave did not exceed official limits and norms, and it is not dangerous for the health of tourists. According to the World Health Organization, the air is not contaminated by fungi if it contains no more than $1500 \mathrm{CFU}$ per $\mathrm{m}^{3}$ of air and if there is a mixture of fungal species (WHO, 1988). In the present study, the observed CFU values, 1284.7 per $\mathrm{m}^{3}$ for outdoor and 89.6 to $217.5 \mathrm{CFU}$ per $\mathrm{m}^{3}$ for indoor air, were similar or lower than those reported by other researchers for cave air or other underground sites (Ogórek et al., 2013, 2014b; Pusz et al., 2014).

The indoor air samples collected inside Driny Cave contained more species of fungi than the outdoor air. This situation may be connected with the limitations of the method of sample collection or may be associated with specific conditions prevailing outside the entrance to the cave, such as temperature and humidity of the air, the vegetation present, the elevation, and the season of the year. It was also stated in the previous reports by Ogórek et al. (2014a, 2014b, 2014c) and Pusz et al. (2014) that most fungal species are transferred to underground sites by air currents from the external environment, which is why Cladosporium spp. dominated in the air both inside and outside of Driny Cave. Moreover, favorable conditions probably caused the domination of species of fungi that are cosmopolitan organisms and produce many spores, such as $C$. cladosporioides. However, Ogórek et al. (2016), who studied fungi cultured 
Table 2. Filamentous fungi and yeast-like fungi isolated from the indoor and outdoor air of Driny Cave, with means of CFU per $\mathrm{m}^{3}$ for six replicated air samples at each location on July 25, 2014.

\begin{tabular}{|c|c|c|c|c|}
\hline $\begin{array}{l}\text { Sampling } \\
\text { Location }^{\mathrm{a}}\end{array}$ & Species & $\begin{array}{l}\text { Air } \pm \text { S.D., } \\
\text { CFU per m }\end{array}$ & $\begin{array}{c}\text { Effect of } \\
\text { Location on } \\
\text { Fungal Species } \\
\text { Isolates }^{\mathrm{b}}\end{array}$ & Percent, $\%$ \\
\hline I & Alternaria alternata & $26.7 \pm 6.8$ & $\mathrm{~b}$ & 2.1 \\
\hline I & Aspergillus niger & $3.0 \pm 1.1$ & $\mathrm{~b}$ & 0.2 \\
\hline I & Cladosporium cladosporioides & $1000.0 \pm 488.1$ & $\mathrm{a}$ & 77.8 \\
\hline I & Cladosporium herbarum & $15.0 \pm 4.1$ & $\mathrm{~b}$ & 1.2 \\
\hline I & Epicoccum nigrum & $140.0 \pm 43.9$ & $\mathrm{~b}$ & 10.9 \\
\hline I & Penicillium urticae & $100.0 \pm 30.8$ & $\mathrm{~b}$ & 7.8 \\
\hline I & Total & $1284.7 \pm 405.8$ & A & 100 \\
\hline II & Candida albicans & $20.0 \pm 4.6$ & c & 13.4 \\
\hline II & Cladosporium cladosporioides & $60.0 \pm 16.7$ & $\mathrm{a}$ & 40.2 \\
\hline II & Cladosporium herbarum & $10.0 \pm 4.2$ & cd & 6.7 \\
\hline II & Penicillium chrysogenum & $13.3 \pm 4.0$ & $\mathrm{~cd}$ & 8.9 \\
\hline II & Penicillium urticae & $33.4 \pm 9.9$ & $\mathrm{~b}$ & 22.4 \\
\hline II & Rhodotorula glutinis & $6.7 \pm 3.0$ & $\mathrm{~d}$ & 4.5 \\
\hline II & Rhodotorula rubra & $5.9 \pm 3.7$ & $\mathrm{~d}$ & 4.0 \\
\hline II & Total & $149.3 \pm 19.8$ & $\mathrm{C}$ & 100 \\
\hline III & Aspergillus fumigatus & $0.2 \pm 0.4$ & $\mathrm{~b}$ & 0.2 \\
\hline III & Cladosporium cladosporioides & $71.1 \pm 21.7$ & $\mathrm{a}$ & 79.4 \\
\hline III & Epicoccum nigrum & $5.6 \pm 3.9$ & $\mathrm{~b}$ & 6.3 \\
\hline III & Fusarium equiseti & $1.2 \pm 1.0$ & $\mathrm{~b}$ & 1.3 \\
\hline III & Penicillium granulatum & $0.8 \pm 0.4$ & $\mathrm{~b}$ & 0.9 \\
\hline III & Penicillium urticae & $6.7 \pm 2.5$ & $\mathrm{~b}$ & 7.5 \\
\hline III & Phoma fimeti & $4.0 \pm 1.9$ & $\mathrm{~b}$ & 4.5 \\
\hline III & Total & $89.6 \pm 25.4$ & $\mathrm{E}$ & 100 \\
\hline IV & Alternaria alternata & $1.1 \pm 1.1$ & $\mathrm{~b}$ & 1.1 \\
\hline IV & Cladosporium cladosporioides & $80.9 \pm 24.1$ & $\mathrm{a}$ & 77.3 \\
\hline IV & Epicoccum nigrum & $7.3 \pm 2.6$ & $\mathrm{~b}$ & 7.0 \\
\hline IV & Fusarium equiseti & $0.2 \pm 0.4$ & $\mathrm{~b}$ & 0.2 \\
\hline IV & Penicillium chrysogenum & $1.7 \pm 1.2$ & $\mathrm{~b}$ & 1.6 \\
\hline IV & Penicillium granulatum & $2.1 \pm 1.3$ & $\mathrm{~b}$ & 2.0 \\
\hline IV & Penicillium urticae & $10.4 \pm 3.4$ & $\mathrm{~b}$ & 9.9 \\
\hline IV & Phoma fimeti & $0.9 \pm 0.3$ & $\mathrm{~b}$ & 0.9 \\
\hline IV & Total & $104.6 \pm 27.3$ & $\mathrm{D}$ & 100 \\
\hline V & Alternaria alternata & $16.7 \pm 2.3$ & $\mathrm{bc}$ & 7.7 \\
\hline V & Aspergillus fumigatus & $3.0 \pm 0.9$ & $\mathrm{c}$ & 1.4 \\
\hline $\mathrm{V}$ & Candida albicans & $0.3 \pm 0.5$ & $\mathrm{c}$ & 0.1 \\
\hline V & Cladosporium cladosporioides & $115.0 \pm 39.2$ & $\mathrm{a}$ & 52.9 \\
\hline $\mathrm{V}$ & Epicoccum nigrum & $26.7 \pm 4.6$ & $\mathrm{~b}$ & 12.3 \\
\hline $\mathrm{V}$ & Mucor hiemalis & $14.1 \pm 3.0$ & $\mathrm{bc}$ & 6.5 \\
\hline $\mathrm{V}$ & Penicillium chrysogenum & $13.2 \pm 3.2$ & $\mathrm{bc}$ & 6.1 \\
\hline V & Penicillium granulatum & $1.8 \pm 1.1$ & $\mathrm{c}$ & 0.8 \\
\hline V & Penicillium urticae & $25.0 \pm 5.3$ & $\mathrm{~b}$ & 11.5 \\
\hline V & Rhodotorula rubra & $1.7 \pm 1.5$ & $\mathrm{c}$ & 0.8 \\
\hline V & Total & $217.5 \pm 34.7$ & B & 100 \\
\hline VI & Alternaria alternata & $15.0 \pm 4.1$ & $\mathrm{c}$ & 7.2 \\
\hline VI & Candida albicans & $5.0 \pm 1.9$ & $\mathrm{c}$ & 2.4 \\
\hline
\end{tabular}


Table 2. Continued.

\begin{tabular}{|c|c|c|c|c|}
\hline $\begin{array}{l}\text { Sampling } \\
\text { Location }^{\mathrm{a}}\end{array}$ & Species & $\begin{array}{l}\text { Air } \pm \text { S.D., } \\
\text { CFU per } \mathrm{m}^{3}\end{array}$ & $\begin{array}{c}\text { Effect of } \\
\text { Location on } \\
\text { Fungal Species } \\
\text { Isolates }^{b}\end{array}$ & Percent, $\%$ \\
\hline VI & Cladosporium cladosporioides & $70.0 \pm 24.4$ & $\mathrm{~b}$ & 33.8 \\
\hline VI & Penicillium chrysogenum & $8.0 \pm 3.2$ & $\mathrm{c}$ & 3.9 \\
\hline VI & Penicillium urticae & $99.0 \pm 32.7$ & a & 47.8 \\
\hline VI & Rhodotorula rubra & $10.0 \pm 4.4$ & $\mathrm{c}$ & 4.8 \\
\hline VI & Total & $207.0 \pm 40.2$ & $\mathrm{~B}$ & 100 \\
\hline
\end{tabular}

${ }^{\text {a }}$ Sampling Station I = Outside the cave; Sampling Stations II-VI = Inside the cave.

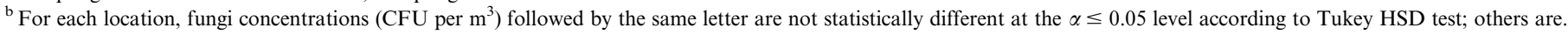
Small letters indicate the effect of location on fungal species isolates. Capital letters indicate the effect of a particular location on total fungal isolates.

from bat guano and air around it in Driny Cave on the same day, reported that the fungus most frequently isolated from the Slovak Speleological Society Hall (Location IV in this paper) was $P$. granulatum. Furthermore, the air around the bat guano contained more species and a higher concentration of airborne fungi than we report here.

According to Domsch et al. (1980), Cladosporium cladosporioides is common in many parts of the world, and its spores can be found in air, soil, and water. Moreover, studies of atmospheric air of various regions in Europe similarly show that the spores of Cladosporium spp. similarly dominate as $80 \%$ of caught spores. The level of concentrations of Cladosporium spores in the air shows a very large variation

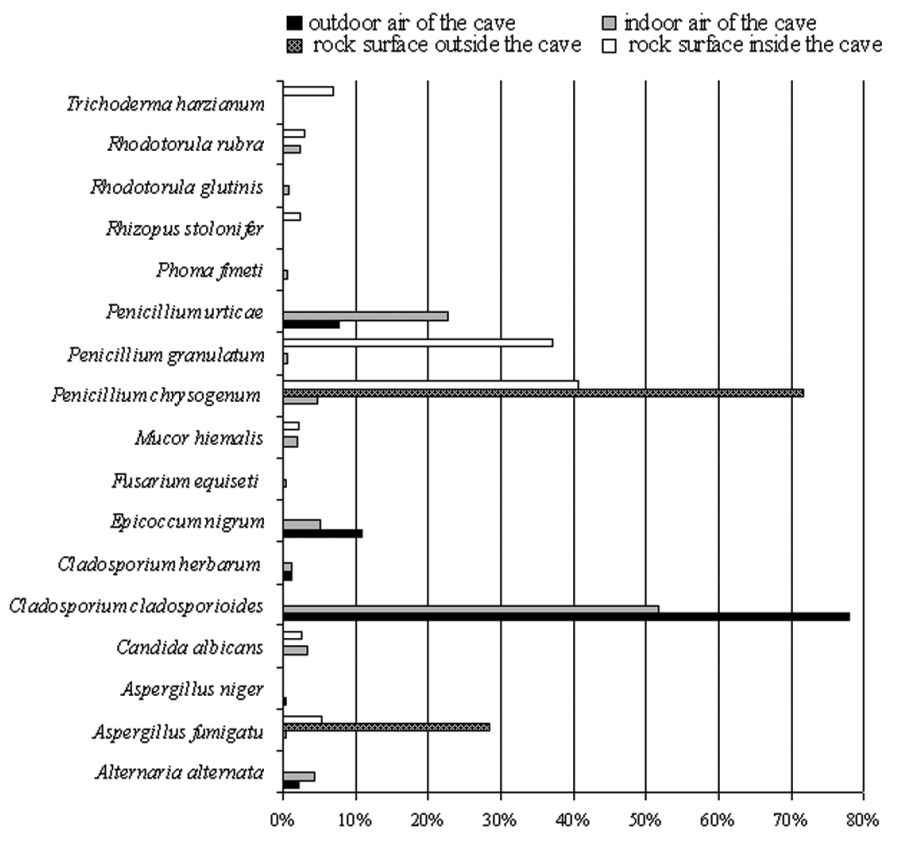

Figure 3. The percentage each species of filamentous and yeast-like fungi isolated contributed to the totals for the air and rock samples taken inside and outside Driny Cave on July 25, 2014. over the year, from zero to several thousand spores per cubic meter, reaching its peak is in the months from June to September (D'Amato and Spieksma, 1995; Lipiec et al., 2000). Our research was conducted during this period, which is particularly conducive for fungal development, due, for example, to the high availability of plant material. Moreover, Cladosporium spp. are classified as inducers of IgE-mediated sensitization and sources of allergic rhinitis or asthma (Douwes et al., 2003; Eduard, 2009). About 2800 spores per liter are necessary to induce symptoms of allergic respiratory system disease in most patients with hypersensitivity to these allergens (Rapiejko et al., 2004). Thus the level of fungi we found does not constitute a significant allergic risk to visitors. However, Cladosporium spp. can be isolated from rocks, and they can cause mineralization of birnessite (Burford et al., 2003). These fungi may secrete acids such as formic, fumaric, gluconic, and lactic and pigments such as melanin, light to dark brown, or gray, and they may cause oxidation of $\mathrm{Fe}(\mathrm{II})$, reduction of $\mathrm{Fe}(\mathrm{III})$ and of $\mathrm{Mn}(\mathrm{IV})$, adsorption of $\mathrm{Cu}^{2+}$, and corrosion of Al (Grote, 1986; Wainwright, 1993; Sterflinger, 2000).

Our results showed that higher numbers of fungi were isolated from the rock surfaces outside the cave (588.5 $\mathrm{CFU} / \mathrm{cm}^{2}$ ) than from the surfaces inside the cave (from 38.3 to 301.7$)$. However, the samples collected inside the cave contained more fungal species than those collected from surfaces located outside the cave. The mean values of CFU per $\mathrm{cm}^{2}$ found in the present study were higher than those noted by other researchers for surfaces located inside different underground sites or caves. During the previous studies, Ogórek et al. (2014b) isolated 113.5 to $185.0 \mathrm{CFU}$ per $\mathrm{cm}^{2}$ from the rock surfaces located inside the underground Rzeczka complex. For comparison, Pusz et al. (2014) collected 24 to $54.9 \mathrm{CFU}$ per $\mathrm{cm}^{2}$ in the case of the Osówka underground complex, and 102.2 to $178.0 \mathrm{CFU}$ per $\mathrm{cm}^{2}$ were isolated by Ogórek et al. (2014a) from the Włodarz underground complex.

According to other authors, the most abundant fungi isolated from rocks belong to such genera as Aspergillus, Aureobasidium, Mucor, Penicillium, Phoma, and Trichoderma (Hirsch et al., 1995; Burford et al., 2003; Ogórek et al., 2014a, 2014b). Our results showed statistically 
R. OGóReK, M. DyląG, Z. VišŇOvSKÁ, D. TANČINOVÁ, AND D. ZALEWSKI

Table 3. Filamentous fungi and yeast-like fungi isolated from the rock surfaces at each location in Driny Cave, with means of CFU per $\mathrm{cm}^{2}$ for nine replicated samples taken on July 25, 2014.

\begin{tabular}{|c|c|c|c|c|}
\hline $\begin{array}{l}\text { Sampling } \\
\text { Location }^{\mathrm{a}}\end{array}$ & Species & $\begin{array}{l}\text { Air } \pm \text { S.D., } \\
\text { CFU per } \mathrm{m}^{3}\end{array}$ & $\begin{array}{c}\text { Effect of } \\
\text { Location on } \\
\text { Fungal Species } \\
\text { Isolates }^{\mathrm{b}}\end{array}$ & Percent, $\%$ \\
\hline I & Aspergillus fumigatus & $166.8 \pm 29.2$ & $\mathrm{~b}$ & 28.3 \\
\hline I & Penicillium chrysogenum & $421.7 \pm 32.0$ & $\mathrm{a}$ & 71.7 \\
\hline I & Total & $588.5 \pm 134.5$ & A & 100 \\
\hline II & Aspergillus fumigatus & $19.1 \pm 4.7$ & $\mathrm{bc}$ & 26.9 \\
\hline II & Candida albicans & $15.0 \pm 3.3$ & $\mathrm{~cd}$ & 21.1 \\
\hline II & Mucor hiemalis & $3.3 \pm 2.0$ & $\mathrm{f}$ & 4.6 \\
\hline II & Penicillium chrysogenum & $10.2 \pm 2.9$ & de & 14.3 \\
\hline II & Penicillium granulatum & $5.2 \pm 2.2$ & $e, f$ & 7.3 \\
\hline II & Rhizopus stolonifer & $18.3 \pm 4.7$ & bc & 25.7 \\
\hline II & Rhodotorula rubra & $23.2 \pm 3.5$ & $\mathrm{~b}$ & 29.7 \\
\hline II & Trichoderma harzianum & $54.9 \pm 4.5$ & $\mathrm{a}$ & 70.3 \\
\hline II & Total & $149.2 \pm 15.6$ & $\mathrm{D}$ & 100 \\
\hline III & Aspergillus fumigatus & $23.8 \pm 3.3$ & $\mathrm{~b}$ & 7.9 \\
\hline III & Penicillium chrysogenum & $265.1 \pm 66.4$ & $\mathrm{a}$ & 87.9 \\
\hline III & Penicillium granulatum & $12.8 \pm 4.0$ & $\mathrm{~b}$ & 4.2 \\
\hline III & Total & $301.7 \pm 124.2$ & $\mathrm{~B}$ & \\
\hline IV & Penicillium chrysogenum & $12.4 \pm 3.6$ & $\mathrm{~b}$ & 5.2 \\
\hline IV & Penicillium granulatum & $228.0 \pm 41.5$ & $\mathrm{a}$ & 94.8 \\
\hline IV & Total & $240.4 \pm 114.5$ & $\mathrm{C}$ & 100 \\
\hline V & Candida albicans & $0.6 \pm 0.5$ & $\mathrm{c}$ & 1.0 \\
\hline V & Mucor hiemalis & $12.7 \pm 2.7$ & $\mathrm{~b}$ & 20.8 \\
\hline V & Penicillium granulatum & $47.8 \pm 4.4$ & $\mathrm{a}$ & 78.2 \\
\hline $\mathrm{V}$ & Total & $61.1 \pm 20.6$ & $\mathrm{E}$ & 100 \\
\hline VI & Candida albicans & $4.9 \pm 1.8$ & $\mathrm{~b}$ & 12.8 \\
\hline VI & Penicillium chrysogenum & $33.4 \pm 7.9$ & $\mathrm{a}$ & 87.2 \\
\hline VI & Total & $38.3 \pm 13.3$ & $\mathrm{~F}$ & 100 \\
\hline
\end{tabular}

${ }^{\text {a }}$ Sampling Station I = Outside the cave; Sampling Stations II-VI = Inside the cave.

${ }^{\mathrm{b}}$ For each location, fungi concentrations (CFU per $\mathrm{m}^{3}$ ) followed by the same letter are not statistically different at the $\alpha \leq 0.05$ level according to Tukey HSD test; others are. Small letters indicate the effect of location on fungal species isolates. Capital letters indicate the effect of a particular location on total fungal isolates.

significant differences in the numbers of fungi isolated from the rocks and differences in the species composition of the fungi most frequently isolated from the rock surfaces. In our study, the most abundant fungi cultured from the rock surfaces were Penicillium chrysogenum, $P$. granulatum and Trichoderma harzianum. These fungi are able to grow in a wide range of temperatures (Rippel-Baldes, 1955; Pusz et al., 2014). It is known that they can degrade a wide range of rocks and minerals (Sterflinger, 2000). They may degrade sandstone, marble, and granite, secrete acids and pigments, and some of them even cause bioconversion of coal. They are also able to solubilize minerals and accumulate metals. For example, Penicillium spp. may secrete acids (citric, 2-oxogluconic, acetic, formic, fumaric, gluconic, glyoxylic, kojic, lactic, malonic, orsellinic, oxalic and tartaric) or different pigments of various colors (grey, orange, purple, red, white, yellow), and they may cause oxidation of $\mathrm{Fe}(\mathrm{II})$ and $\mathrm{Mn}(\mathrm{II})$, adsorption of $\mathrm{Al}, \mathrm{Zn}, \mathrm{Cd}$, $\mathrm{U}, \mathrm{Th}, \mathrm{Pb}, \mathrm{Sn}$, solubilization of rock phosphate and coal, and reduction of Fe(III) (Sterflinger, 2000; Cwalina, 2008). In addition, these fungi can cause mineralization of materials such as halloysite $\left(\mathrm{Al}_{2} \mathrm{Si}_{2} \mathrm{O}_{5}(\mathrm{OH})_{4} \cdot 2 \mathrm{H}_{2} \mathrm{O}\right)$ and montmorillonite $\left((\mathrm{Na}, \mathrm{Ca})_{0.33}(\mathrm{Al}, \mathrm{Mg})_{2}\left(\mathrm{Si}_{4} \mathrm{O}_{10}\right)(\mathrm{OH})_{2} \cdot n \mathrm{H}_{2} \mathrm{O}\right)$ or todorokite ( $\mathrm{Mn}, \mathrm{Ca}, \mathrm{Mg}) \mathrm{Mn}_{3} \mathrm{O}_{12} \cdot 3 \mathrm{H}_{2} \mathrm{O}$ ) (Burford et al., 2003). Trichoderma spp. may secrete acids, such as acetic, citric, formic, gluconic, glyoxylic, and oxalic, and green pigments. This species is able to oxidize sulfide groups, solubilize coal, and accumulate $\mathrm{Cd}, \mathrm{Cu}$, and even uranium (Sterflinger, 2000).

\section{Conclusions}

Our results show that the external environment around the cave directly affects the concentration of fungal 
propagules and their species composition inside the studied area. The mean number of fungi was higher outside than inside Driny Cave, but the samples collected from inside contained a higher number of fungal species than samples collected outside the cave. The widely recognized and accepted standards for airborne fungi are not exceeded in Driny Cave; therefore, this place does not constitute a health risk to visiting tourists. The most frequently isolated fungus from the indoor and outdoor air was Cladosporium cladosporioides, a cosmopolitan organism predominant in the atmosphere, especially during the summertime. The fungi most frequently isolated from the rock surfaces were Penicillium chrysogenum, $P$. granulatum, and Trichoderma harzianum. It should be noted that the species of fungi isolated from the rock surfaces can cause their slow degradation. We believe that this type of research allows people to better understand the cave ecosystems, in particular to characterize the underground mycobiota and their role in the occupied ecological niche.

\section{ACKNOWLEDGEMENTS}

We thank Dr. Ján Zuskin, director of Slovak Caves Administration, for his help in the study. This work was co-financed by the Ministry of Science and Higher Education carried out by the University of Wroclaw "Grant to Young Researchers". Grant number: 0420/1398/16.

\section{REFERENCES}

Al-Doory, Y., and Rhoades, E.R., 1968, Isolation of Histoplasma capsulatum from a Texas cave: Mycopathologia et Mycologia Applicata, v. 35, no. 3, p. 201-207. doi:10.1007/BF02050730.

Balabanoff, V.A., 1967, Etudes comparées des Dermatophytes isolés de grottes et d'étables en Bulgarie: Mycopathologia et Mycologia Applicata, v. 32, no. 3, p. 237-248. doi:10.1007/BF02049801.

Barnett, J.A., Payne, R.W., and Yarrow, D., 2000, Yeasts: Characteristics and Identification, third edition: Cambridge, Cambridge University Press, $1150 \mathrm{p}$.

Barton, H.A., 2006, Introduction to cave microbiology: A review for the non-specialist: Journal of Cave and Karst Studies, v. 68, no. 2, p. 43-54.

Barton, H.A., and Northup, D.E., 2007, Geomicrobiology in cave environments: Past, current, and future perspectives: Journal of Cave and Karst Studies, v. 69, no. 1, p. 163-178.

Bastian, F., Jurado, V., Nováková, A., Alabouvette, C., and Saiz-Jimenez, C., 2010, The microbiology of Lascaux Cave: Microbiology, v. 156, no. 3, p. 644-652. doi:10.1099/mic.0.036160-0.

Bella, P., 2003, Slovensko - Sprístupnené Jaskyne (Slovakia Show Caves): Liptovský Mikuláš, Grafon, $64 \mathrm{p}$.

Bella, P., Hlavac, J., and Gazik, P., 2001, Protection and management of show caves in Slovakia: $13^{\text {th }}$ International Congress of Speleology, $4^{\text {th }}$ Speleological Congress of Latin América and the Caribbean, $26^{\text {th }}$ Brazilian Congress of Speleology, Brasília, 15-22, July, 2001, p. 287-290.

Brashear, D., Wiseman R.F., and Barr Jr., T.C., 1966, A psychrophilic yeast from Mammoth Cave, Kentucky: International Journal of Speleology, v. 2, no. 4, p. 403-404. doi:10.5038/1827-806X.2.4.12.

Burford, E.P., Kierans M., and Gadd, G.M., 2003, Geomycology: Fungi in mineral substrata: Mycologist, v. 17, no. 3, p. 98-107. doi:10.1017/ S0269915X03003112.

Chelius, M.K, Beresford, G., Horton, H., Quirk, M., Selby, G., Simpson, R.T., Horrocks, R., and Moore, J.C., 2009: Impacts of alterations of organic inputs on the bacterial community within the sediments of Wind Cave, South Dakota, USA. International Journal of Speleology, v. 38 , no. 1 , p. 1-10. doi: 10.5038/1827-806X.38.1.1.

Cury, G.C., Dinez Filho, A., Cruz, A.G.C., and Hobaika, A.B.S., 2001. Surto de histoplasmose em Pedro Leopoldo, Minas Gerais, Brasil. (Outbreak of histoplasmosis in Pedro Leopoldo, Minas Gerais, Brazil): Revista Sociedade Brasileira de Medicina Tropical, v. 34, no. 5, p. 483-486. doi:10.1590/S0037-86822001000500013.

Cwalina, B., 2008, Biodeterioration of concrete: Architecture Civil Engineering Environment, v.1, no. 4, p. 133-140.

D'Amato, G., and Spieksma, F.Th.M., 1995, Aerobiologic and clinical aspects of mould allergy in Europe: Allergy, v. 50, no. 11, p. 870-877. doi:10.1111/j.1398-9995.1995.tb02492.x.

Domsch, K.H., Games, W., and Anderson, T.H., 1980, Compendium of Soil Fungi: London, Academic Press, 1264 p.

Douwes, J., Thorne, P., Pearce N., and Heederik, D., 2003, Bioaerosol health effects and exposure assessment: Progress and prospects: The Annals of Occupational Hygiene, v. 47, no. 3, p. 187-200. doi:10.1093/annhyg/meg032.

Eduard, W., 2009, Fungal spores: A critical review of the toxicological and epidemiological evidence as a basis for occupational exposure limit setting: Critical Reviews in Toxicology, v. 39, no. 10, p. 799-864. doi: $10.3109 / 10408440903307333$.

Griffin, D.W., Gray, M.A., Lyles, M.B., and Northup, D.E., 2014, The transport of nonindigenous microorganisms into caves by human visitation: A case study at Carlsbad Caverns National Park: Geomicrobiology Journal, v. 31, no. 3, p. 175-185. doi:10.1080/01490451.2013. 815294.

Grote, G., 1986, Mikrobieller Mangan- und Eisentransfer an Rock Varnish und Petroglyphen arider Gebiete [PhD thesis]: University of Oldenburg, Germany, 335 p.

$\mathrm{Gu}$, Ji-Dong, 2003, Microbiological deterioration and degradation of synthetic polymeric materials: Recent research advances: International Biodeterioration \& Biodegradation, v. 52, no. 2, p. 69-91. doi:10.1016/ S0964-8305(02)00177-4.

Hirsch, P., Eckhardt, F.E.W., and Palmer, R.J., Jr., 1995, Fungi active in weathering of rock and stone monuments: Canadian Journal of Botany, v. 73, no. S1, p. 1384-1390. doi:10.1139/b95-401.

Jurado, V., Laiz, L., Rodriguez-Nava, V., Boiron, P., Hermosin, B., Sanchez-Moral, S., and Saiz-Jimenez, C., 2010, Pathogenic and opportunistic microorganisms in caves: International Journal of Speleology, v. 39, no. 1 , p. 15-24. doi:10.5038/1827-806X.39.1.2.

Kaiser, K., and Wolski, A., 2007, Kontrola czystości mikrobiologicznej powietrza (Control of microbiological purity of air): Technika Chłodnicza i Klimatyzacyjna, no. 135, p. 158-162.

Kalogerakis, N., Paschali, D., Lekaditis, V.,Pantidou, A., Elefheriadis, K., and Lazarides, M., 2005, Indoor air quality-bioaerosol measurements in domestic and office premises: Journal of Aerosol Science, v. 36, no. 5-6, p. 751-761. doi:10.1016/j.jaerosci.2005.02.004.

Karkun, A., Tiwari, K.L., and Jadav, S.K., 2012, Fungal diversity of Mandeepkhol Cave in Chhattisgarh, India: Advances in Bioresearch, v. 3, no. 2, p. 119-123.

Koilraj, A.J., and Marimuthu, G., 1998, Algal flora in the cave soils: Current Science, v. 75 , no. 11 , p. 1111-1113.

Kubátová, A., and Dvořák, L., 2005, Entomopathogenic fungi associated with insect hibernating in underground shelters: Czech Mycology, v. 57 , no. $3-4$, p. $221-237$.

Kurtzman, C.P., and Fell, W., eds., 1998, The Yeasts, a Taxonomic Study, fourth edition: Amsterdam, Elsevier, 1076 p.

Lehotská, B., and Lehotský, R., 2009, 15 rokov zimného monitoringu netopierov v jaskyni Driny ( 15 years of winter monitoring of bats in the Driny Cave): Aragonit, v. 14, no. 2, p. 171-172.

Li, Xianshu, Arai, H., Shimoda, I., Kuraishi, H., and Katayama, Y., 2008, Enumeration of sulfur-oxidizing microorganisms on deteriorating stone of the Angkor monuments, Cambodia: Microbes and Environments, v. 23, no. 4, p. 293-298. doi:10.1264/jsme2.ME08521.

Lipiec, A., Jurklewicz, D., and Rapiejko, P., 2000, Mould hypersensitivity in allergic rhinitis patients: International Review of Allergology and Clinical Immunology, v. 6, p. 57-63.

Nudziková, L., 2014, Vývoj návštevnosti sprístupnených jaskýň na Slovensku od roku 2009 (Course of show caves attendance in Slovakia since 2009): Aragonit, v. 19, no. 1-2, p. 35-38.

Ogórek, R., Lejman, A., and Matkowski, K., 2013, Fungi isolated from the Niedźwiedzia Cave in Kletno (Lower Silesia, Poland): International 
Journal of Speleology, v. 42, no. 2, p. 161-166. doi: 10.5038/1827806X.42.2.9.

Ogórek, R., Pusz, W., Lejman, A., and Uklańska-Pusz, C., 2014a, Microclimate effects on number and distribution of fungi in the underground comlex in the Owl mountains (Góry Sowie), Poland: Journal of Cave and Karst Studies, v. 76, no. 2, p. 146-153. doi:10.4311/ $2013 \mathrm{MB} 0123$.

Ogórek, R., Pusz, W., Matkowski, K., and Pląskowska, E., 2014b, Assessment of abundance and species composition of filamentous fungi in the underground Rzeczka complex in Sowie Mountains (Lower Silesia, Poland): Geomicrobiology Journal, v. 31, no. 10, p. 900-906. doi:10.1080/01490451.2014.907380.

Ogórek, R., Lejman, A., and Matkowski, K., 2014c, Influence of the external environment on airborne fungi isolated from a cave: Polish Journal of Environmental Studies, v. 23, no. 2, p. 435-440.

Ogórek, R., and Lejman, A., 2015, Badania speleomikologiczne w wybranych obiektach podziemnego kompleksu Riese (Góry Sowie, Dolny Śląsk, Polska) / (Speleomycological research in the selected objects of underground Riese complex (Sowie Mountains, Lower Silesia, Poland)): Postępy Mikrobiologii, v. 54, no. 4, p. 344-353.

Ogórek, R., Pląskowska, E., Dylag,, M., Višňovská, Z., Tančinová, D., and Lejman, A., Fungi isolated and quantified from bat guano and air in Harmanecká and Driny Caves (Slovakia): Journal of Cave and Karst Studies, v. 78, no. 1, p. 41-49. doi:10.4311/2015MB0108.

Papuas, G.P., Herbert, R.J., Henderson, W., Koenig, J., Stover, B., and Barnhart, S., 2000, The respiratory effects of volatile organic compounds: International Journal of Occupational and Environmental Health, v. 6, no. 1, p. 1-8. doi:10.1179/oeh.2000.6.1.1.

Pitt, J.I., and Hocking, A.D., 2009, Fungi and Food Spoilage, third edition: Dordrecht, Springer, $519 \mathrm{p}$.

Poulson, T.L., and White, W.B., 1969, The cave environment: Science, v. 165 , no. 3897 , p. $971-981$. doi:10.1126/science.165.3897.971.

Pulido-Bosch, A., Martín-Rosales, W., López-Chicano, M., RodríquezNavarro, C.M., and Vallejos, A., 1997, Human impact in a tourist karstic cave (Aracena, Spain): Environmental Geology, v. 31, no. 3-4, p. 142-149. doi:10.1007/s002540050173.

Pusz, W., Ogórek, R., Knapik, R., Kozak, B., and Bujak, H., 2015, The occurrence of fungi in the recently discovered Jarkowicka cave in the Karkonosze Mts. (Poland): Geomicrobiology Journal, v. 32, no. 1, p. 59-67. doi:10.1080/01490451.2014.925010.

Pusz, W., Ogórek, R., Uklańska-Pusz, C.M., and Zagożdżon, P., 2014, Speleomycological research in underground Osówka complex in Sowie Mountains (Lower Silesia, Poland): International Journal of Speleology, v. 43 , no. 1 , p. 27-34. doi: 10.5038/1827-806X.43.1.3.
Rapiejko, P., Lipiec, A., Wojdas, A., and Jurkiewicz, D., 2004, Threshold pollen concentration necessary to evoke allergic symptoms: International Review of Allergology and Clinical Immunology, v. 10, p. 91-94.

Rippel-Baldes, A., 1955, Grundzüge der Mikrobiologie, third edition: Berlin, Springer, 418 p. doi: 10.1007/978-3-662-01454-7.

Scheerer, S., Ortega-Morales, O., and Gaylarde, C., 2009, Microbial deterioration of stone monuments: An updated overview: Advances in Applied Microbiology, v. 66, p. 97-139. doi:10.1016/S0065-2164(08) 00805-8.

Sterflinger, K., 2000, Fungi as geologic agents: Geomicrobiology Journal, v. 17 , no. 2 , p. 97-124. doi:10.1080/01490450050023791.

Šustr, V., Elhottová, D., Krištůfek, V., Lukešova, A., Nováková, A., Tajovský, K., and Tř́ska, J., 2005, Ecophysiology of the cave isopod Mesoniscus graniger (Frivaldszky 1865) (Crustacea: Isopoda): European Journal of Soil Biology, v. 41, no. 3-4, p. 69-75. doi:10.1016/j.ejsobi. 2005.09.008.

Taylor, E.L.S., Resende-Stoianoff, M.A.R., and Lopes Ferreira, R., 2013, Mycological study for a management plan of a neotropical show cave (Brazil): International Journal of Speleology, v. 42, no. 3, p. 267-277. doi: 10.5038/1827-806X.42.3.10.

Vanderwolf, K.J., Malloch, D., McAlpine, D.F., and Forbes, G.J., 2013, A world review of fungi, yeasts, and slime molds in caves: International Journal of Speleology, v. 42, no. 1, p. 77-96. doi: 10.5038/1827806X.42.1.9.

Wainwright, M., 1993, Oligotrophic growth of fungi-stress or natural state? in Jennings, D.H., ed., Stress Tolerance of Fungi: New York, Marcel Dekker, Mycology Series 10, p. 127-144.

Walochnik, J., and Mulec, J., 2009, Free-living amoebae in carbonate precipitating microhabitats of karst caves and a new vahlkampfiid amoeba, Allovahlkampfia spelaea gen. nov., sp. nov.: Acta Protozoologica, v. 48 , no. 1, p. $25-33$.

Watanabe, T., 2010, Pictorial Atlas of Soil and Seed Fungi: Morphologies of Cultured Fungi and Key to Species, third edition: Boca Raton, Florida, CRC Press, $426 \mathrm{p}$.

Wiejak, A., 2011, Ocena stopnia skażenia powietrza zarodnikami grzybów pleśniowych jako czynnik ekspertyzy mikologicznej (The assessment of air contamination with the mould fungi spores as an Essentials factor of mycological report): Prace Instytutu Techniki Budowlanej, v. 3, no. 159 , p. 3-12.

WHO (World Health Organization), 1988, Indoor Air Quality: Biological Contaminants, Report on a WHO Meeting, Rautavaara, 29 August2 September 1988: Copenhagan, WHO Regional Office for Europe, WHO Regional Publications, European Series no. 31, 67 p. 